Received: 5 March 2018

Accepted: 18 May 2018

Online: 21 May 2018

Authors:

Nurcan Yigit $\bigotimes$, BurakAaricak

Department of Forest Engineering, Faculty of

Forestry, Kastamonu University, Turkey

Mehmet Cetin

Department of Landscape Architecture, Faculty of Engineering and Architecture, Kastamonu

University,Turkey

Hakan Sevik

Department of Environmental Engineering,

Faculty of Engineering and Architecture,

Kastamonu University, Turkey

$\bigotimes$ nyigit@kastamonu.edu.tr

Emer Life Sci Res (2018) 4(1): 45-52

E-ISSN: 2395-6658

P-ISSN: 2395-664X

DOI: https://doi.org/10.31783/elsr.2018.414552

\section{Research Article \\ Variation of some micro-morphological characters of leaves of Aesculus hippocastanum based on growing environment}

\author{
Nurcan Yigit, Mehmet Cetin, Hakan Sevik, Burak Aricak
}

\begin{abstract}
Buckeye (Aesculus hippocastanum L.) is a member of the family Sapindaceae and is an exotic species for Turkey. It is a kind of tree that can grow up to an average of 15-20 m and is deciduous, which we often see in parks, gardens and roadsides. Although it is not in the natural flora of Turkey due to the use of different areas especially in the city centers, it is being used in the areas where many different climate types dominate. In this study, it was aimed to determine the variation of some micromorphological characters of the leaves of Aesculus hippocastanum L. depending on the growing environment. Samples were grown on 6 different cities which are dominated by different climate types. With this purpose, leaf samples were collected from Aesculus hippocastanum L. individuals growing in 6 different cities (Rize, Samsun, İzmir, Antalya, Sivas and Ankara) in the Central and Western Anatolia regions where the Black Sea, Mediterranean and continental climate types predominate. Scale images were obtained with the help of electron microscope (SEM = Scanning Electron Microscope) of the collected leaf samples and stoma length $(\mu \mathrm{m})$, stoma width $(\mu \mathrm{m})$, por length $(\mu \mathrm{m})$, por width and stoma density (per $\mathrm{mm}^{2}$ field) were determined. Variance analysis and Duncan test were applied to the obtained data with the help of SPSS package program and the variation of the indicated characters according to the growing environment was evaluated statistically. As a result of the study, it was determined that there was a statistically significant difference in at least $95 \%$ confidence level among the growth environment conditions for all characters except for stoma width.
\end{abstract}

Keywords Aesculus hippocastanum L., buckeye, micro-morphological character, SEM, Stoma

\section{Introduction}

Due to the rapidly growing population in the world, the green spaces in cities are under constant threat, which is leading to various environmental problems including noise, air pollution and unplanned urbanization [1-4]. Gradually congested large settlements are increasing the need of people for natural and green areas. Accordingly, the importance of the landscape design in the city centers and plants existence have increased and started to be accepted as a sign of the quality and livability of cities [3, 5-11]. The plants are able to adapt to different growing environments around the world, especially due to the varying size, density and distribution of stoma on the leaf surfaces [12-14].

Just like in natural areas, plants perform many functions in the city centers, such as being an economic resource, decreasing the speed 
of the wind and supporting the wild life [15-17]. In addition to these, they add aesthetic value to the growing areas [18-19]. Therefore, the use of plants outside the natural environment is a common occurrence in landscape studies.

Table 1. Some climate data of the sample areas

\begin{tabular}{|l|c|c|c|c|c|c|}
\hline \multicolumn{1}{|c|}{ Annual Avarage Values } & Rize & Samsun & İzmir & Antalya & Sivas & Ankara \\
\hline Average Temperature $\left({ }^{\circ} \mathrm{C}\right)$ & 14.3 & 14.5 & 17.8 & 18.6 & 8.9 & 11.9 \\
\hline Average Maximum Temperature $\left({ }^{\circ} \mathrm{C}\right)$ & 18.0 & 18.2 & 22.6 & 24.1 & 15.3 & 17.8 \\
\hline Average Minimum Temperature $\left({ }^{\circ} \mathrm{C}\right)$ & 11.1 & 11.0 & 13.4 & 13.7 & 2.8 & 6.2 \\
\hline Average Sunshine Time (hours) & 49.4 & 61.0 & 94.5 & 100.3 & 80.5 & 80.3 \\
\hline Average Number of Rainy Days & 172.5 & 135.6 & 77.7 & 75.1 & 112.5 & 102.3 \\
\hline Total Rainfall Amount $(\mathrm{kg} / \mathrm{m} 2)$ & 2304.1 & 717.5 & 695.9 & 1066.9 & 429.2 & 387.2 \\
\hline Highest Temperature $\left({ }^{\circ} \mathrm{C}\right)$ & 38.2 & 39.0 & 43.0 & 45.0 & 40.0 & 41.0 \\
\hline Lowest Temperature $\left({ }^{\circ} \mathrm{C}\right)$ & -7.0 & -9.8 & -8.2 & -4.6 & -34.6 & -24.9 \\
\hline
\end{tabular}

In landscaping studies, plants are often left alone with the stress factors (water, light, temperature, etc.), depending on whether the plants are used outside the natural spreading area or not. These stress factors are likely to affect the morphological and micro-morphological properties of the plants [19-21].

One of the first places where people and trees are closest and where they are most useful to each other is the roadside planting areas. In fact, trees, which are a part of the forest ecosystem, are under the influence of various pressures on roadsides where urban ecosystem and urban constructions are dominant. Due to these pressures, they grow more slowly and live shorter than their homologues in natural life [22].

Among the countries in the temperate zone, Turkey is one of the countries with the richest flora in the world in terms of number of species [23]. In Turkey, plant species that are grown in three different phytogeographic regions can be used in landscape designs. These plants generally do not differ significantly from one another morphologically at first glance. Nevertheless, there is not enough information about how they differ at the micro-morphological level. However, the changes that occur at fairlysmall levels can give many ideas, from the stress level of the plant to the level of adaptation to their growth environment [24].

Aesculus hippocastanum L. is one of the tree species that spread in areas where different climate types dominate. Buckeye (Aesculus hippocastanum L.) is a member of the family Sapindaceae and is deciduous. Although their main homeland is the Balkan peninsula, it also grows naturally in Albania and northern Greece. Today, it is widely used as a shadow and alley tree. This species that can grow up to 20-30 $\mathrm{m}$, has 5-7 pieces of fuzzy leaves and standing upright flowers. Buckeyes are often grown in parks, gardens and roadsides as ornamental plants because of their beautiful and eye-catching flowers and large leaves. In this study, it was aimed to determine the changes in micro-morphological characters of leaves of Aesculus hippocastanum L. individuals, which were grown in areas that are dominated by different climate types (Black Sea, Mediterranean and continental).

Table 2. Variation of leaf micromorphological characters depending on growth environment

\begin{tabular}{|l|c|c|c|c|c|}
\hline \multirow{2}{*}{ City } & \multicolumn{5}{|c|}{ micromorphological characters } \\
\cline { 2 - 6 } & STU $(\boldsymbol{\mu m})$ & STG $(\boldsymbol{\mu m})$ & PORU $(\boldsymbol{\mu m})$ & PORG $(\boldsymbol{\mu m})$ & STY (number) \\
\hline Ankara & $16,388 \mathrm{a}$ & $9,709 \mathrm{a}$ & $6,713 \mathrm{a}$ & $2,041 \mathrm{a}$ & $288 \mathrm{~d}$ \\
\hline Antalya & $31,222 \mathrm{~b}$ & $23,689 \mathrm{~b}$ & $\mathbf{1 4 , 9 7 6} \mathbf{c}$ & $\mathbf{5 , 4 8 0} \mathbf{c}$ & $208 \mathrm{c}$ \\
\hline Samsun & $18,304 \mathrm{a}$ & $10,237 \mathrm{a}$ & $12,184 \mathrm{~b}$ & $4,026 \mathrm{c}$ & $139 \mathrm{~b}$ \\
\hline İzmir & $\mathbf{4 3 , 3 5 5} \mathbf{c}$ & $\mathbf{3 0 , 3 6 2 ~ b}$ & $14,798 \mathrm{c}$ & $1,920 \mathrm{a}$ & $145 \mathrm{~b}$ \\
\hline Rize & $19,769 \mathrm{a}$ & $12,023 \mathrm{a}$ & $11,362 \mathrm{~b}$ & $2,679 \mathrm{ab}$ & $97 \mathrm{a}$ \\
\hline Sivas & $16,714 \mathrm{a}$ & $9,387 \mathrm{a}$ & $6,340 \mathrm{a}$ & $2,175 \mathrm{ab}$ & $309 \mathrm{e}$ \\
\hline F Value & $40,766^{* * *}$ & $59,711^{* * *}$ & $24,770 * * *$ & $47,222^{* * *}$ & $594,840 * * *$ \\
\hline
\end{tabular}




\section{Methodology}

The study was carried out on leaves of Aesculus hippocastanum L. that were collected from different cities. Aesculus hippocastanum L. is an exotic species in Turkey that can be grown in areas dominated by different types of climate. The leaf samples used in the study were collected from Samsun and Rize that are dominated by Black Sea climate type; Izmir and Antalya that are dominated by Mediterranean climate type; and Ankara and Sivas provinces that are dominated by continental climate type. Even when these cities are in the same regions and dominated by the same climate types, there is a great difference between the climate data of the cities. Some of the climate data of the cities from where the leaf samples were collected are given in Table 1

Mature leaf samples from Aesculus hippocastanum L. individuals, which were located in parks, gardens and roadsides in urban centers from İzmir, Antalya, Samsun, Rize, Ankara and Sivas were collected in 2016. They were collected late in the vegetation season, and were pressed dried by standard pressing process and drying method. Further, leaf samples were brought to Central Research Laboratory of Kastamonu University, examined with electron microscopy and necessary images were taken. With the help of SEM, scaled images were obtained from the lower surface of the leaf and near the middle parts. The files were created with the extension ".jpeg" and by the "ImageJ" program;STU: Stoma Length, STG: Stoma Width, PORU: Pore length, PORG: Pore width and STY: Stomach Density $\left(1 \mathrm{~mm}^{2}\right.$ field) were measured.

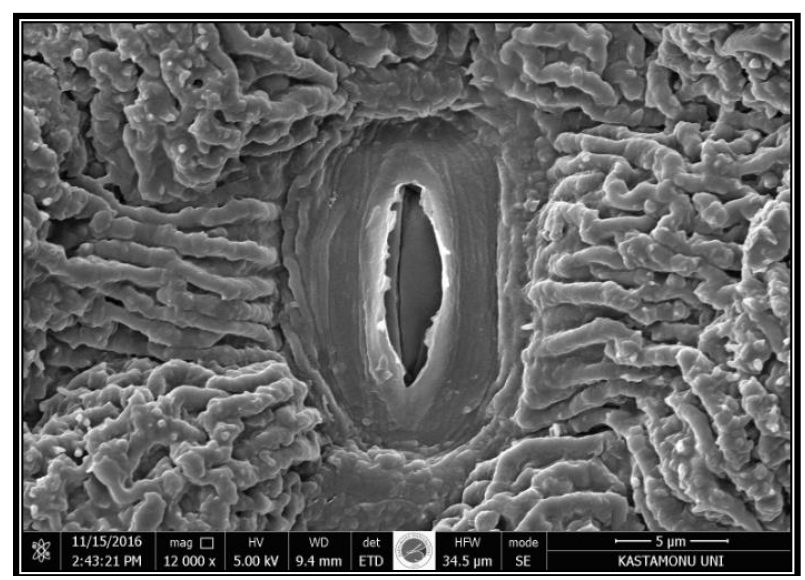

A

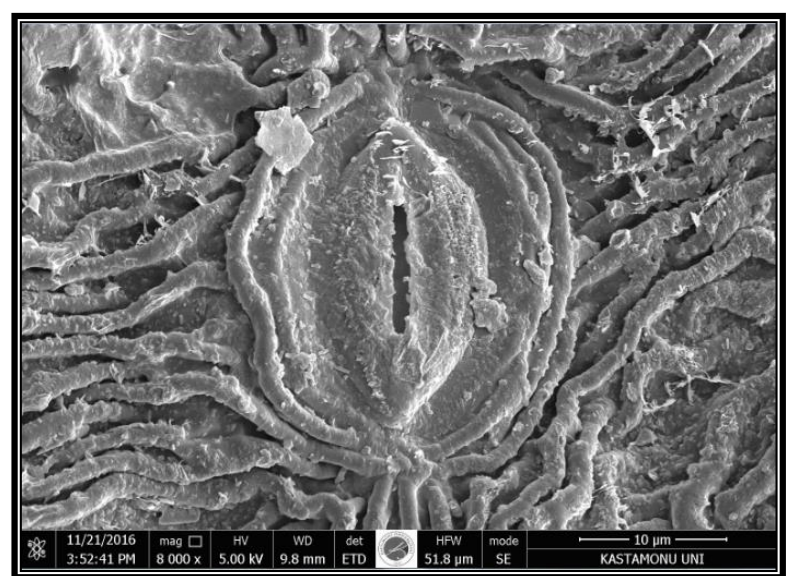

B

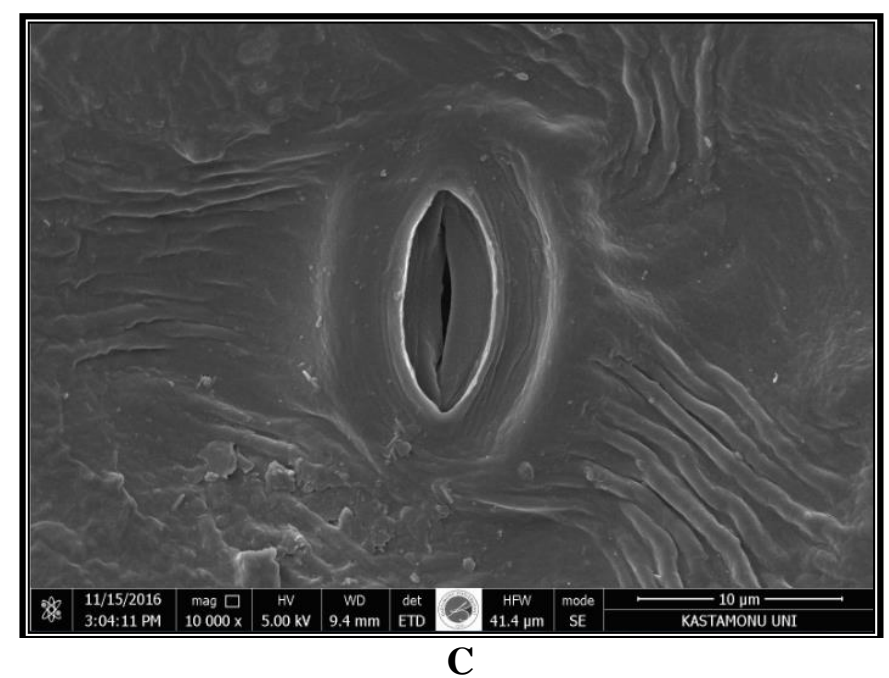

Figure 1. In general adaxial surface of Aesculus hippocastanum L. individuals from different Phytogeographic region (A) Europe-Siberia (Bar $5 \mu \mathrm{m})$ (B) Iran-Turan (Bar $10 \mu \mathrm{m})$ (C) Mediterranean Phytogeographic region Bar $10 \mu \mathrm{m}$ 
Aesculus hippocastanum L. leaf samples were measured after the images were obtained from the lower surface and the obtained data were evaluated with SPSS package program and variance analysis and Duncan test were applied to the data. Correlation analysis was applied to the data with the help of SPSS package program in order to determine the existence of statistically significant relationship between the examined micro-morphological characters.

\section{Results and Discussion}

The mean values of the micro-morphological characters in the leaves of Aesculus hippocastanum L. collected from İmir, Antalya, Samsun, Rize, Ankara and Sivas which were located in the different phytogeographical regions; and the variance analysis and Duncan test results applied to this data are given in Table 2. As the result of the variance analysis, it was determined that there was a statistically significant difference of $99.9 \%$ confidence level among the individuals which were grown in different cities in terms of all the investigated micro-morphological characters. According to the Duncan test results, the data were collected in three homogeneous groups as STG, PORU and PORG, two STG and five STY homogeneous groups. Duncan test results showed that Ankara and Sivas were in the first homogeneous groups in all the characters other than STY and they usually had the lowest values. For the other characters outside the STY, the highest values were obtained in Izmir and Antalya samples. The lowest values for STY were measured in Rize and Samsun. The change in stoma density can be considered as one of the clearest indicators of the environmental changes.

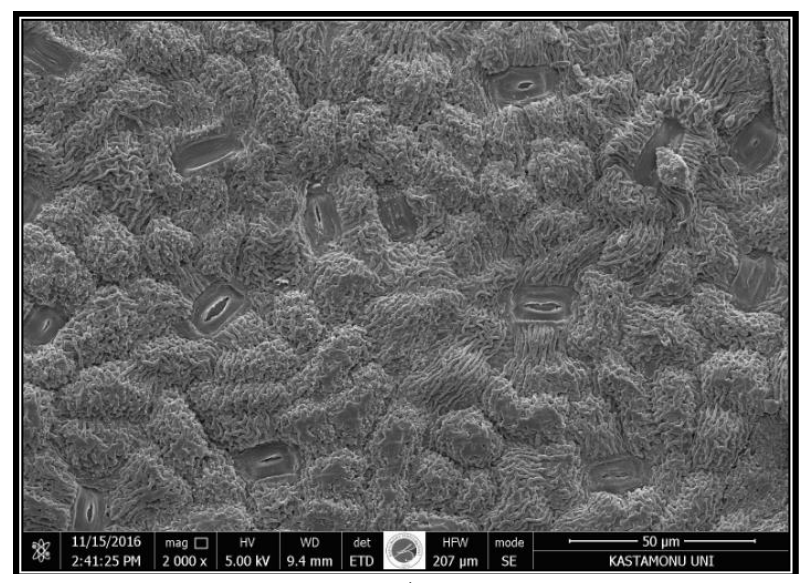

A

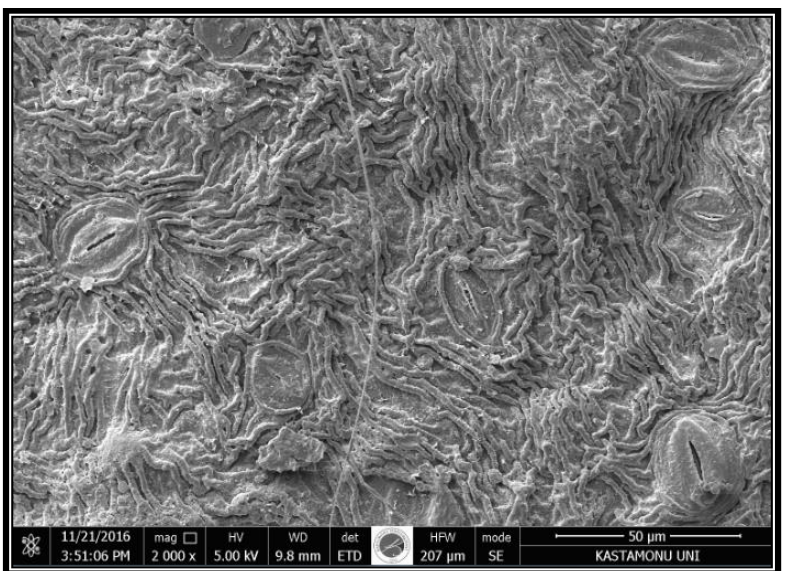

B

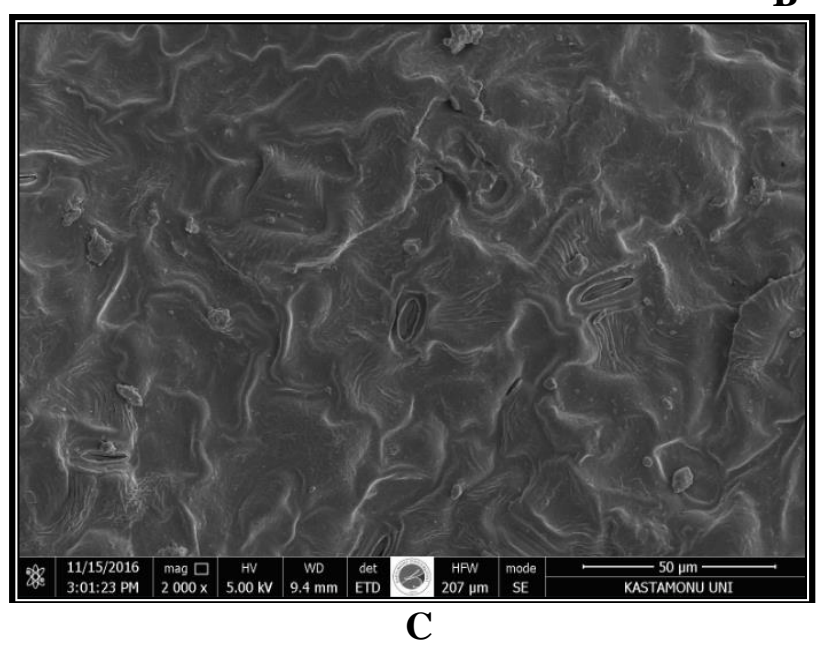

Figure 2. Mature leaf samples from Aesculus hippocastanum L. individuals from different phytogeographic region (A) Europe-Siberia (Bar $50 \mu \mathrm{m})(B)$ Iran-Turan (Bar $50 \mu \mathrm{m})$ (C) Mediterranean Phytogeographic region Bar $50 \mu \mathrm{m}$ 
Table 3. Results of correlation analysis

\begin{tabular}{|l|c|c|c|c|}
\hline & STU & \multicolumn{1}{|c|}{ STG } & PORU & PORG \\
\hline STG &, $909 * *$ & & & \\
\hline PORU &, $769 * *$ &, $741 * *$ & & \\
\hline PORG &, 073 &, 197 &, $479 * *$ & \\
\hline STY &,$- 301 *$ &,$- 319 *$ &,$- 567 * *$ &,- 167 \\
\hline
\end{tabular}

Mature leaf samples from Aesculus hippocastanum L. individuals from different phytogeographic regions have been demonstrated in Figure 1. Epidermal cells of the abaxial surface were striated at the same level. Stoma appeared normal and were clearly visible with guard cells that were generally lacking folds (Figure 1). Adaxial surface of mature leaves of Aesculus hippocastanum L. individuals from different phytogeographic regions have been demonstrated in Figure 2.

Correlation analysis was applied to the data to determine the statistical significance of the obtained data (Table 3). According to the results of the correlation analysis, it was determined that the relationship between PORG and STU, STG and STY was not statistically significant; while there was a statistically significant relation between all the other characters. The relationship between the two variables according to Cohen [25], the correlation coefficient value was low between 0.10-0.29, medium level between 0.30-0.49 and high level between 0.50-1.0. Accordingly, the strongest correlations were found between STU and STG (0.909) and PORU (0.769). There was also a moderately strong relationship between PORU and STG and STY at high level, PORU with PORG (0.479) and STY with STU (0.301) and STG (0.319). All relations between STY and other characters were negative. Several studies have already reported that the size of the stoma is inversely proportional to the number [26-27].

It is noteworthy that among most of the characters studied other than the STY, the highest values were from Izmir and Antalya. Ankara and Sivas are dominated by continental climate and İzmir and Antalya are in the areas dominated by the Mediterranean climate. The lowest average temperature values were found in Ankara and Sivas, and the highest average temperature values were found in Izmir and Antalya. This leads to the conclusion that the stoma characters were related to the climate and especially to the temperature. Stoma characters have been associated with the climate type in the studies of different species [28-30].

The study results showed that the stoma characters were closely related to each other. Phenotypic characters appeared by the interaction of the genetical and environmental changes [31] and they were formed by the effect of many environmental factors [32-34] and genetical factors [35-36]. However, it has been determined that the morphological characteristics of the species vary depending on many factors, especially the origin [37-39].

Studies have shown that micro-morphological characters vary significantly from species to species [26]. The stoma control the $\mathrm{CO}_{2}$ and water vapor entry to the leaves and are significantly affected by the environmental conditions [40-43]. When plants are cultivated in an area outside the natural growth environment, some changes in their own structure occur to get them adapted to the growing environment. Plant species used in the landscape designs usually also deal with the stress factors, depending on the usage of plants outside the natural spreading areas. It is known that these stress factors affect some morphological properties of the plants. For morphological and physiological reasons, structural features of stoma, the number and the distribution of stomas on leaf surface have been the subject of many researches. Studies have shown that the plant morphological characteristics are influenced by many stress factors such as light, salt stress [44-45], and water stress [46]. Therefore, it is possible that stoma characters are affected by environmental conditions and especially stress factors [47-48]. Several studies have addressed that among different stoma characters, stoma density is highly affected by these factors [28-30]. 


\section{Acknowledgements}

This study is supported by Kastamonu University Scientific Research Projects Coordination Unit (project number: KÜBAP-01/2016-12). We thanks to Kastamonu University Scientific Research Projects Coordination Unit.

\section{References}

[1] S. Mansuroğlu, T. Birişçi, Z. Sögüt and Ö. A. Kalaycı (2016). The importance of ecological balance protection of roof garden applications in mediterranean climate, 1st International Mediterranean Science and Engineering Congress (IMSEC 2016), October, pp 26-28.

[2] T. Birişçi, S. G. Mansuroğlu, Z. Söğüt and A. K. Önaç (2017a). Ağaç, Çevre ve Toprak. Yaşamın Her Karesinde Toprak. İstanbul Aydın Üniversitesi Yayınları. ISBN: 978-605-4303-80-9. http://yasaminherkaresindetoprak.aydin.edu.tr/yaseminherkaresindetoprak.pdf

[3] T. Birişçi, S. Mansuroğlu, Z. Söğüt, A. Kalaycı Önaç and V.Dağ (2017b). Doğa Dostu Peyzaj Uygulamalar1. International Conference on Agriculture, Forest, Food Sciences and Technologies. 15-17 Mayis, Kapadokya.

[4] C. Yücedağ and L. G. Kaya (2016). Impacts of air pollutants to plants. MAKÜ, FEBED., 7: 67-74.

[5] C. O. Alpay, A. Kalaycı and T. Birişçi (2013). Ekolojik tasarım kriterlerine göre kent parkı iyileştirme modeli; izmir kültürpark örneği, TMMOB 2. Kent Sempozyumu, İzmir.

[6] N. Yiğit, A. Ozturk and H. Şevik (2014). Ecological impact of urban forests (example of kastamonu urban forest). Int. J. Eng. Sc1. Res. Technol., 3: 558-562.

[7] S. Öztürk and E. Bozdoğan (2015). The contribution of urban road trees on improving the air quality in an urban area. Fresenius Environ. Bull., 24: 1822-1829.

[8] T. B. Randrup, C. Konijnendijk, M. K. Dobbertin and R. Prüller (2005). The concept of urban forestry in europe. In urban forests and trees (pp. 9-21). Springer, Berlin, Heidelberg.

[9] Z. Söğüt, S. Mansuroğlu, T. Birişçi and Ö. A.Kalayc1 (2016). Improving the active green space ratio in coastal cities in turkey. . 5th fábos conference on landscape and greenway planning. pp515-522. 30 June- 3 July 2016, Budapest, Hungary. https://drive.google.com/file/d/0B0SDfwlPIez6cktlbXZYU3J0TUk/view

[10] C. Yücedağ, L. G. Kaya and A. Ulu (2017). Investigation of landscape design efficiency in the housing development and the apartment complexes of burdur city, turkey. MAKÜ FEBED., 8: 114-122.

[11] L. G. Kaya, C. Yücedağ and B. Bingöl (2017). Usage of ineffective mining quarries for recreational purposes: the case study of burdur city, turkey. The Journal of Graduate School of Natural and Applied Sciences of Mehmet Akif Ersoy University, 8: 184-190.

[12] F. Zarinkamar (2006). Density, size and distribution of stomata in different monocotyledons. Pak. J. Biol. Sci., 9: 1650-1659.

[13] E. Kırdar, H. B. Özel and M. Ertekin (2010). Effects of pruning on height and diameter growth at stone pine (Pinus pinea L.) Afforestations. Bartın Orman Fakültesi Dergisi, 12: 1-10.

[14] H. B. Özel and M. Ertekin (2012). The change of stand structure in uludağ fir (Abies nordmanniana subsp. bornmuelleriana mattf.) forests along an altitudinal gradient. Kastamonu University Journal of Forestry Faculty, 12(3): 96-104.

[15] M. D. Kantarc1, H. B. Özel, M. Ertekin and E. Kırdar (2011). An assessment on the adaptation of 6 tree species to steppe habitat during konya-karapinar sand-dune afforestations. Bartın Orman Fakültesi Dergisi, 13: 107-127.

[16] H. B. Özel (2008). Impact of forest restoration practices on the some soil properties in bartýn-ardýç district. Ekoloji J., 18: 14-19.

[17] M. Ertuğrul, T. Varol and H. B. Özel (2014). Climate changes in prospect for the west black sea forests. Bartın Orman Fakültesi J., 16: 35-43.

[18] A. K. Önaç and T. Biriş̧̧i (2017). Evaluating ege unıversity campus transportation network based on human-oriented design criteria. The Journal of Academic Social Science Studies. 54: 333-349. Doi: http://dx.doi.org/10.9761/JASSS6906. 
[19] M. Cetin, N. Yigit, H. B. Ozel and H. Sevik (2017). The changing of leaf micromorphogical characters on grown in different growth conditions in Buxus sempervirens plants. Nature, Environment and Earth Science.

[20] Z. Lu, M.A. Quinones and E. Zeiger (1993). Abaxial and adaxial stomata from pima cotton (Gossypium barbadense L.) differ in their pigment content and sensitivity to light quality. Plant Cell Environ., 16: 851-885.

[21] G. J. Retallk (2001). A 300-million-year record of atmospheric carbon dioxide from fossil plant cuticles. Nature, 411: 287-290.

[22] İ. Aslanboğa (1986). Kentlerde yol ağaçlaması. Tübitak Yapı Araştırma Enstitüsü Yayını, No: U3, Ankara.

[23] A. Yıldırım (1993). Biyocografya. Palme Yayınları, Ankara.

[24] H. Sevik, M. Cetin and B. Aricak (2017b). The variable of leaf micromorphogical characters on grown in distinct climate conditions in some landscape plants. International Journal of Arts \& Sciences' (IJAS) International Conference for Physical, Life and Health Sciences, Las Vegas, Nevada, USA. 13-17 March 2017.

[25] J. Cohen (1988). Statistical Power Analysis for the Behavioral Sciences. 2nd edn.

[26] J. Galmés, J. Flexas, R. Savé and H. Medrano (2007). Water relations and stomatal characteristics of mediterranean plants with different growth forms and leaf habits: responses to water stress and recovery. Plant and Soil, 290: 139-155.

[27] A. M. Hetherington and F. I. Woodward (2003). The role of stomata in sensing and driving environmental change. Nature, 424: 901-908.

[28] J. M. Dunlap and R. F. Stettler (2001). Variation in leaf epidermal and stomatal traits of populus trichocarpa from two transects across the washington cascades. Can. J. Bot., 79: 528-536.

[29] A. M. Bosabalidis and G. Kofidis (2002). Comparative effects of drought stress on leaf anatomy of two olive cultivars. Plant science, 163: 375-379.

[30] M. Guerfel, O. Baccouri, D. Boujnah, W. Chaïbi and M. Zarrouk (2009). Impacts of water stress on gas exchange, water relations, chlorophyll content and leaf structure in the two main Tunisian olive (Olea europaea L.) cultivars. Sci. Hort., 119: 257-263.

[31] H. Sevik, Z. Yahyaoglu and I. Turna (2012). Determination of genetic variation between populations of abies nordmanniana subsp. bornmulleriana mattf according to some seed characteristics, Genetic Diversity in Plants, InTech, ISBN 978-953-51-0185-7, Chapter 12, pp:231-248.

[32] A. Turkyilmaz, H. Sevik and M. Cetin (2018). The use of perennial needles as biomonitors for recently accumulated heavy metals. Landsc. Ecol. Eng., 14: 115-120.

[33] H. Sevik and M. Cetin (2015). Effects of water stress on seed germination for select landscape plants. Pol. J. Environ. Stud., 24: 689-693.

[34] O. Topacoglu, H. Sevik and E. Akkuzu (2016). Effects of Water Stress on Germination of Pinus nigra Arnold. Seeds, Pak. J. Bot., 48: 447-453.

[35] H. Sevik (2012). Variation in seedling morphology of Turkish fir (Abies nordmanniana subsp. bornmulleriana Mattf), Afr. J. Biotechnol., 11: 6389-6395.

[36] C. Yücedağ, B. Bingöl, L.G. Kaya (2016). Forest Genetic Resources in Burdur, Turkey. Mehmet Akif Ersoy Üniversitesi, Journal of Economics and Administrative Sci., 3: 6-12.

[37] N. Yigit, , H. Sevik, , M. Cetin and N. Kaya (2016). Determination of the effect of drought stress on the seed germination in some plant species. In Water Stress in Plants, In Tech. chapter pp: 43-62. ISBN: 978-953-51-2621-8.

[38] N. Bilir, K. Canpolat and M. D. Ulusan (2010). Morphological characters and quality in Stone pine (Pinus pinea L.) seedlings of aydin provenance. Kastamonu University Journal of Forestry Faculty, 10: 37-43.

[39] Z. Yahyaoğlu, A. Demirci, N. Bilir and M. Genç (2001). Comparison of 22 taurus cedar (Cedrus libani A. Rich.) origins by seedling morphological distance. Turk. J. Biol., 25: 221-228.

[40] Z. Xu and G. Zhou (2008). Responses of leaf stomatal density to water status and its relationship with photosynthesis in a grass. J. Exp. Bot., 59: 3317-3325. 
[41] F. B. Salisbury and C. W. Ross (1985). Plant Physiology. (Third Edition). Wadsworth Publishing Co., Belmont, California, 540p.

[42] H. M. Yang and G. X. Wang (2001). Leaf stomatal densities and distribution in Triticum aestivum under drought and $\mathrm{CO}_{2}$ enrichment. Acta Phytoecologica Sinica, 25: 312-316.

[43] S. Liu, J. Liu, J. Cao, C. Bai and R. Shi (2006). Stomatal distribution and character analysis of leaf epidermis of jujube under drought stress. Journal of Anhui Agricultural Science, 34: 1315-1318.

[44] R. X. Zhao, Q. B. Zhang, X. Y. Wu and Y. Wang (2001). Effects of drought on epidermal cells and stomatal density of wheat leaves. Inner Mongolia Agricultural Science and Technology. 6: 6-7.

[45] R. Romero-Aranda, T. Soria and J. Cuartero (2001). Tomato plant-water uptake and plant-water relationships under saline growth conditions. Plant Sci., 160: 265-272.

[46] R. Ferris, I. Nijs, T. Beaeghe and I. Impens (1996). Elevated CO2 and temperature have different effects on leaf anatomy of perennial ryegrass in spring and summer. Ann. Bot. 78, 489-497.

[47] S. Banon, J. A. Fernandez, J. A. Franco, A. Torrecillas, J. J. Alarcón and M. J. Sánchez-Blanco (2004). Effects of water stress and night temperature preconditioning on water relations and morphological and anatomical changes of Lotus creticus plants. Sci. Hort., 101: 333-342.

[48] D. J. Beerling, C. K. Kelly and E. J. Salisbury (1997). Stomatal density of temperature woodland plants over the past seven decades of CO2 increase: a comparison of Salisbury (1927) with contemporary data. Am. J. Bot., 84: 1572-1583. 